\title{
Communities of Microscopic Fungi in Dead Spruce in Relation to the Season and Degree of Wood Decay in Poland's Karkonosze Mountains
}

\author{
Wojciech Pusz ${ }^{1 *}$, Rafal Ogórek² \\ ${ }^{1}$ Department of Plant Protection, Wroclaw University of Environmental and Life Sciences, Wroclaw, Poland \\ ${ }^{2}$ Department of Mycology and Genetics, Institute of Genetics and Microbiology, \\ University of Wroclaw, Wroclaw, Poland
}

Received: 14 November 2018

Accepted: 24 July 2019

\begin{abstract}
Towards the end of the $20^{\text {th }}$ century the Karkonosze Mountains in southwestern Poland were characterized by vast swathes of dead and dying spruce forests whose condition at the time was described as an ecological disaster. Wood-decaying fungi play an important role in global carbon and nitrogen circulation by promoting the bioconversion of organic matter. The aim of our study was to determine the composition of the fungal community in the 'post-disturbance' dead spruce wood in relation to the season and degree of wood decay in the Karkonosze Mountains. Mycological analyses were carried out in 2015 and 2016 in the submontane and mountain forest zone, as well as in the subalpine zone of Karkonoski National Park (KNP). The findings reveal that the prevalent fungi colonising the internal tissues of dead wood belonged to the genus Trichoderma. Their proportion in the material under study increased in advanced stages of wood decay. However, the mycobiota of dead spruce at lower levels of decay were characterized by the highest diversity. The analysis also showed seasonal variations in the composition of the fungal communities colonizing dead wood.
\end{abstract}

Keywords: fungi, dead spruce, stage of decay, Karkonosze Mountains

\section{Introduction}

By the end of the $20^{\text {th }}$ century the Karkonosze Mountains in southwestern Poland were largely associated with vast swathes of land covered by dead or dying spruce forests [1]. Their condition was dire enough

*e-mail: wojciech.pusz@upwr.edu.pl to be regarded as an ecological disaster, and the blame was placed entirely on air pollution and acid rain. It is now a well-established fact that this was a multi-stage and multi-component process, and that these stages and components comprised, inter alia, herbivorous insect gradation, the presence of spruce monocultures and atmospheric conditions [2]. According to Manion [3], the phenomenon was also a consequence of the so-called 'decline disease spiral', which is a group of factors that 
contribute to the decline of a forest and that adversely affect one another, ultimately leading to the destruction of the ecosystem. Moreover, as demonstrated by Manion [3], tree diseases serve a purpose in nature, even if they occur on a large scale. More and more scientists believe that the process taking place in the Sudeten Mountains is neither isolated nor particularly extraordinary. It does, however, possess the characteristics of an ecological disturbance, although the extent to which human activity has contributed to it remains largely unknown. Moreover, it appears to be a recurring event. The research and experimentation revolving around remedial measures indicate that its effects might be reversible, and knowledge of the processes involved is likely to enable effective repair of the damage [4].

Dead wood is an essential component of the forest ecosystem [5]. It is crucial to the survival of saproxylic organisms that recycle nutrients and initiate the renewal of subsequent generations of trees and other organisms, including fungi [6]. Moreover, fungal endophytes are probably involved in triggering the early stages of wood decay [7]. This is one of the reasons why it has been suggested that dead wood provides indispensable nourishment for more than 1500 species of mostly microscopic fungi as well as 1300 insect species and ca. 100 species of vertebrates [8]. It should be noted that out of all fungi, the microscopic species are the least well-known, despite the important role they play in the decomposition of dead wood [9]. Wood-decaying fungi contribute to the global carbon and nitrogen cycle by promoting the bioconversion of organic mater. Therefore, identifying communities of these fungi, their colonization strategies and mechanisms of decomposition, as well as the factors influencing them, may help develop our understanding of the nutrients circulating in forest ecosystems. This knowledge may help develop new vaccines, allow for the decomposition of the stumps and roots of felled trees, and facilitate composting, as well as the preliminary processing of timber intended for the production of bioethanol [10].

The aims of this study were: (i) identify the composition of fungal communities in dead spruce wood in the Karkonosze Mountains and (ii) assess to what extent the structure of these communities depends on the stage of wood decay, and whether or not it is subject to seasonal fluctuations.

\section{Material and Methods}

Mycological monitoring of the 'post-disturbance' spruce wood (Picea abies (L.) H.Karst) was carried out three times in each growing season: in spring, summer and autumn, within the KNP (Poland), in 2015 and 2016. In the first year of the study, the sites included four areas of mountain forest and the subalpine zone of the western part of the KNP: Chojnik, Mumlawski Peak, Szrenica and Szrenicki Cirque. In the next year the sites were chosen in the submontane zone (under KNP management since 1 January 2016, i.e. Żar Mountain and Szerzawa), in mountain forests and the subalpine zone (Petrovka, Wilcza Poręba, Łomniczka Cirque, Łomniczka Valley, Skalny Stół), as well as in the vicinity of the Czech mountain shelter 'Jelenka'. In the course of the study the degree of wood decomposition was determined with the help of Pyle and Brown's scale [11] and the relevant classes were used in the description. The geographical coordinates and the altitude (above sea level) were measured using a Garmin 62s GPS device. The samples were taken within a 20-metre radius of the recorded coordinates (Table 1).

Table 1. Detailed information about sampling points.

\begin{tabular}{|c|c|c|c|c|}
\hline \multirow{2}{*}{ Year } & \multicolumn{2}{|c|}{ Location } & \multirow{2}{*}{ Geographic coordinates } & \multirow{2}{*}{ Height a.s.1. [m] } \\
\hline & Name & Abbreviation & & \\
\hline \multirow{4}{*}{$\stackrel{n}{\stackrel{n}{\nu}}$} & Chojnik & $\mathrm{C}$ & $\mathrm{N} 50^{\circ}$ 50.369', E15 $38.465^{\prime}$ & 414 \\
\hline & Kocioł Szrenicki & $\mathrm{KS}$ & $\mathrm{N} 50^{\circ} 47.440^{\prime}, \mathrm{E}^{\circ} 5^{\circ} 31.905^{\prime}$ & 1109 \\
\hline & Mumlawski Szczyt & M & N50 47.820', E15² 29.539’ & 1134 \\
\hline & Szrenica & $\mathrm{S}$ & N50 47.913', E15 29.976' & 1093 \\
\hline \multirow{8}{*}{$\stackrel{0}{\stackrel{0}{\circ}}$} & Dolina Łomniczki & $\mathrm{D}$ & $\mathrm{N} 50^{\circ} 45.214^{\prime}, \mathrm{E} 15^{\circ} 44.888^{\prime}$ & 971 \\
\hline & Góra Żar & G & $\mathrm{N} 50^{\circ} 49.547^{\prime}, \mathrm{E}^{\circ} 5^{\circ} 38.010^{\prime}$ & 613 \\
\hline & Jelenka & $\mathrm{J}$ & $\mathrm{N} 50^{\circ} 44.553^{\prime}, \mathrm{E}^{\circ} 5^{\circ} 46.450^{\prime}$ & 1319 \\
\hline & Kocioł Łomniczki & K & $\mathrm{N} 50^{\circ} 44.584^{\prime}, \mathrm{E} 15^{\circ} 44.111^{\prime}$ & 1102 \\
\hline & Petrovka & $\mathrm{P}$ & N50 47.909', E15 $37.099^{\prime}$ & 806 \\
\hline & Skalny Stół & Ss & $\mathrm{N} 50^{\circ} 45.097^{\prime}, \mathrm{E}^{\circ} 5^{\circ} 47.393^{\prime}$ & 1221 \\
\hline & Szerzawa & $\mathrm{Sz}$ & $\mathrm{N} 50^{\circ} 48.968^{\prime}, \mathrm{E}^{\circ} 5^{\circ} 37.979^{\prime}$ & 676 \\
\hline & Wilcza Poręba & W & $\mathrm{N} 50^{\circ} 45.835^{\prime}, \mathrm{E}^{\circ} 5^{\circ} 45.334^{\prime}$ & 665 \\
\hline
\end{tabular}


The samples were taken from three stumps of dead spruce trees or fallen spruce trunks, which were stripped of their bark using a sterile knife. Pieces of wood were then extracted with a sterile scalpel from a depth of approximately $1-2 \mathrm{~cm}$ and placed in sterile string bags. A laboratory analysis of the samples was carried out within three days of their collection. The wood fragments were divided into pieces of approximately $1 \mathrm{~cm}$ and underwent a 30-second-long process of superficial disinfection with a $1 \%$ solution of sodium hypochlorite. They were then placed in batches of six in Petri dishes with a PDA medium (Potato Dextrose Agar, Biocorp) in 10 replicates. In order to eliminate bacteria from the fungal samples, a $0.5 \%$ solution of acetic acid was added to the medium [12]. The biological material was incubated in Petri dishes for 4 to 14 days at $25 \pm 0,2^{\circ} \mathrm{C}$. The individual colonies of fungi grown from the wood samples were then counted and explanted onto the PDA medium.

Pure fungal cultures, obtained through the use of the single-spore method, were identified according to the methodology commonly employed in mycological laboratories, i.e., the methodology based on the macroscopic and microscopic appearance of the cultures and reference information in the monographic and diagnostic keys [13-34]. The majority of the fungi were identified on the PDA medium, but Penicillium and Aspergillus species were identified by growing them on the following additional media: malt extract agar (MEA, Biocorp), Czapek-Dox agar (1.2\% agar, Biocorp) and Czapek yeast autolysate agar (CYA): $30.0 \mathrm{~g} \cdot \mathrm{L}^{-1}$ sucrose, $15 \mathrm{~g} \cdot \mathrm{L}^{-1}$ agar, $5.0 \mathrm{~g} \cdot \mathrm{L}^{-1}$ yeast extract, $3.0 \mathrm{~g} \cdot \mathrm{L}^{-1}$
$\mathrm{NaNO}_{3}, 1.0 \mathrm{~g} \cdot \mathrm{L}^{-1} \mathrm{~K}_{2} \mathrm{HPO}_{4}, 0.5 \mathrm{~g} \cdot \mathrm{L}^{-1} \mathrm{KCl}, 0.5 \mathrm{~g} \cdot \mathrm{L}^{-1}$ $\mathrm{MgSO}_{4} \cdot 7 \mathrm{H}_{2} \mathrm{O}, 0.01 \mathrm{~g} \cdot \mathrm{L}^{-1} \mathrm{FeSO}_{4} \cdot 7 \mathrm{H}_{2} \mathrm{O}$.

\section{Results}

In the two years of the study a total of 30 species of fungi were isolated, of which 25 were collected in 2016 and 20 in 2015 (Figs 1-2). The biodiversity of the fungi depended on the decay class of the wood and the time of sampling. Wood in the initial stages of decomposition was colonized by a greater variety of fungi. The correlation between the time of sampling and the number of isolated fungi was not confirmed until the second year of the study. Samples taken in spring exhibited the greatest biodiversity regardless of the degree of wood decomposition, with wood in the first decay class being the only exception (Table 2, Table 3 ).

The largest number (16) of fungi cultured in 2015 came from spruce samples taken in summer, while the lowest number (9) came from material sampled in spring (Fig. 1). Taking into account the degree of wood decomposition, the spruce wood sampled in summer and classified as decay class 3 contained the highest number of fungal species (12), whereas the samples taken in spring and classified as decay class 1 did not contain any fungi at all. However, during the spring and autumn sampling periods, material classified as decay class 2 was characterized by the highest fungal biodiversity (Table 2).

In 2016, the greatest number (21) of fungi was grown from spruce wood samples taken in spring, while

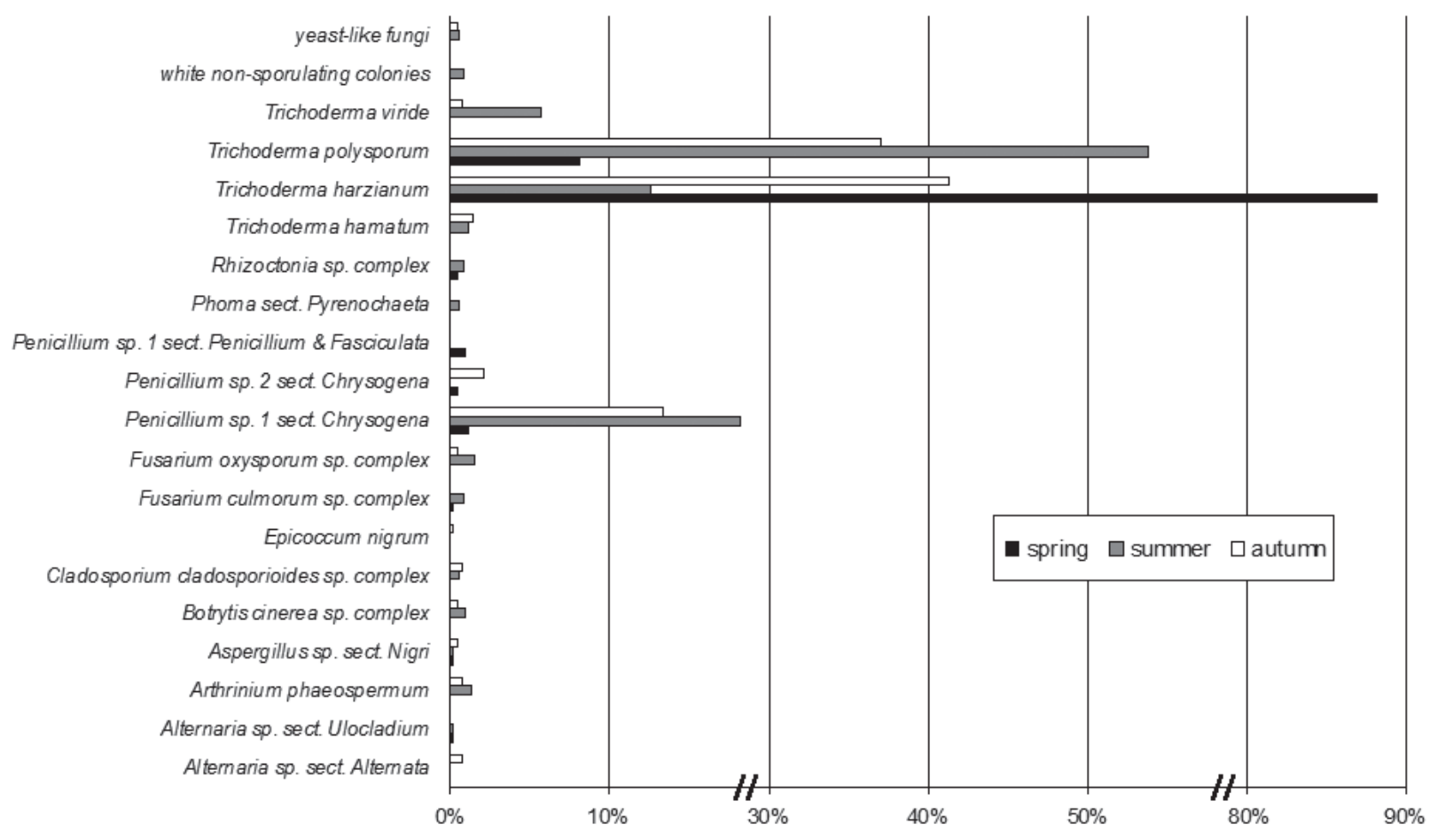

Fig. 1. Percentage of each fungus contributing to the totals for the dead spruce wood samples in 2015. 


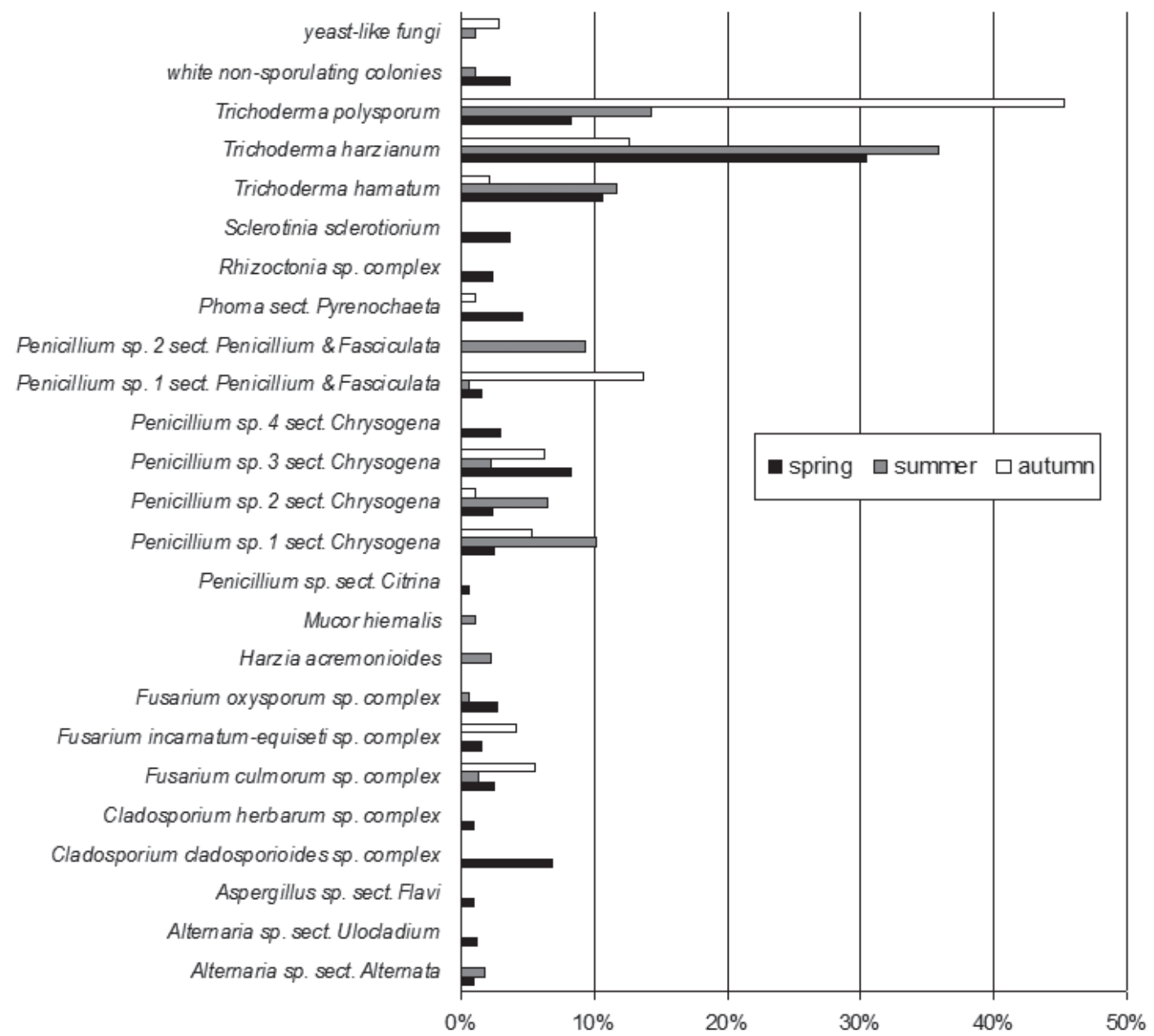

Fig. 2. Percentage of each fungus contributing to the totals for the dead spruce wood samples in 2016.

the fewest (11) were cultured from the material sampled in autumn (Figs 1-2). In terms of wood decay classes, spring samples in decay class 4 were characterized by the greatest fungal biodiversity. Autumn samples assigned to decay classes 1 and 3 contained the lowest number of fungal species ( 3 per sample). In the summer, the samples with the highest fungal biodiversity were those in decay class 1, whereas during the autumn sampling those were classified as decay class 5 (Table 3).

Fungi of the genus Trichoderma were isolated from dead spruce wood in all decay classes, at all sampling sites and in both years of the study (Tables 2 and 3). Moreover, Trichoderma spp. was the dominant species in the fungal communities colonizing the samples, with the proportion of other taxa in the same samples reaching $<10 \%$ - especially in the case of wood in the final stages of decomposition. The species most frequently isolated in both spring samplings, as well as in the autumn of 2015 and in the summer of 2016, was Trichoderma harzianum. However, in the summer of 2015 and the autumn of 2016, the dominant species turned out to be T. polysporum (Figs 1 and 2).

\section{Discussion}

Because fungi are so diverse - more than five million species have been described to date [35] - their identification to species level is, in many cases, difficult. This is particularly true when only one identification method is employed, such as the classical diagnostic one based on the phenotype of the fungus and an assessment of its biochemical capacity, or in a situation where only a single genetic marker is used [17, 32, 36, 37]. In the case of the classical identification method, the composition of the culture medium and the conditions of incubation also play an important role. Only in fungi do the aforementioned factors determine the appearance of the colony and, in many cases, facilitate the production of distinctive morphological forms (such as fungal spores) that can prove useful in the identification process [36]. This is why the majority of the fungi analyzed using the classical method can be identified down to a specific complex, genus or section $[37,38]$. This is one of the reasons why most of the fungi sampled in this study were identified as belonging to a complex (e.g., the C. cladosporioides sp. complex) or a section (e.g., $A$. sp. sect. Flavi) in accordance with the most recent suggestions and recommendations. 
Table 2. Microscopic fungi isolated from dead spruce in 2015: I - spring, II - summer, III - autumn; A (+) indicates the presence of fungi.

\begin{tabular}{|c|c|c|c|c|c|c|c|c|c|c|c|c|c|c|c|c|c|c|}
\hline \multirow{3}{*}{ Fungi } & \multicolumn{15}{|c|}{ Wood on decomposition scale } & \multirow{2}{*}{\multicolumn{3}{|c|}{ Sampling location }} \\
\hline & \multicolumn{3}{|c|}{1} & \multicolumn{3}{|c|}{2} & \multicolumn{3}{|c|}{3} & \multicolumn{3}{|c|}{4} & \multicolumn{3}{|c|}{5} & & & \\
\hline & $\mathrm{I}$ & II & III & $\mathrm{I}$ & II & III & $\mathrm{I}$ & II & III & $\mathrm{I}$ & II & III & I & II & III & I & II & III \\
\hline Alternaria sp. sect. Alternata & & & & & & + & & & & & & & & & & & & $\mathrm{C}, \mathrm{KS}, \mathrm{M}^{*}$ \\
\hline Alternaria sp. sect. Ulocladium & & & & + & & & & + & & & & & & & & $\mathrm{M}, \mathrm{S}$ & $\mathrm{M}$ & $\mathrm{KS}$ \\
\hline Arthrinium phaeospermum & & & + & & & & & + & & & & & & & & & M & $\mathrm{KS}$ \\
\hline Aspergillus sp. sect. Nigri & & & + & + & & & & & & & + & & & & & $\mathrm{M}, \mathrm{C}$ & $\mathrm{C}, \mathrm{S}$ & \\
\hline Botrytis cinerea sp. complex & & & + & & & & & + & & & & & & & & & $\mathrm{KS}$ & $\mathrm{KS}$ \\
\hline $\begin{array}{l}\text { Cladosporium cladosporioides sp. } \\
\text { complex }\end{array}$ & & + & + & & & & & & & & & & & & & & KS & $\mathrm{KS}$ \\
\hline Epicoccum nigrum & & & & & & & & & & & & + & & & & & & $\mathrm{S}$ \\
\hline Fusarium culmorum sp. complex & & + & & + & & & & + & & & & & & & & $\mathrm{KS}, \mathrm{M}$ & KS & \\
\hline Fusarium oxysporum sp. complex & & + & & & & + & & + & & & & & & & & & KS & $\mathrm{C}$ \\
\hline Penicillium sp. 1 sect. Chrysogena & & + & & + & + & + & + & + & + & + & + & + & & & & $\begin{array}{l}\mathrm{KS}, \\
\mathrm{M}, \mathrm{S}\end{array}$ & $\begin{array}{l}\mathrm{KS}, \\
\mathrm{M}, \mathrm{S}\end{array}$ & $\mathrm{M}, \mathrm{S}$ \\
\hline Penicillium sp. 2 sect. Chrysogena & & & & + & & + & + & & + & & & & & & & $\mathrm{M}, \mathrm{S}$ & & $\mathrm{C}, \mathrm{M}$ \\
\hline $\begin{array}{l}\text { Penicillium sp. } 1 \text { sect. Penicillium } \\
\text { \& Fasciculata }\end{array}$ & & & & + & & & + & & & & & & & & & $\mathrm{M}, \mathrm{S}$ & & \\
\hline Phoma sect. Pyrenochaeta & & + & & & & & & & & & & & & & & & $\mathrm{KS}$ & \\
\hline Rhizoctonia sp. complex & & & & + & & & & + & & & & & & & & M & KS & \\
\hline Trichoderma hamatum & & & & & + & + & & + & & & + & + & & & & & \begin{tabular}{|c|}
$\mathrm{C}, \mathrm{M}$ \\
$\mathrm{S}$
\end{tabular} & $\begin{array}{l}\mathrm{C}, \mathrm{KS} \\
\mathrm{M}, \mathrm{S}\end{array}$ \\
\hline Trichoderma harzianum & & & + & + & + & + & + & + & + & + & + & + & + & + & + & $\begin{array}{l}\mathrm{C}, \mathrm{KS}, \\
\mathrm{M}, \mathrm{S}\end{array}$ & \begin{tabular}{|c|}
$\mathrm{C}, \mathrm{KS}$ \\
$\mathrm{M}$
\end{tabular} & $\begin{array}{l}\mathrm{C}, \mathrm{KS} \\
\mathrm{M}, \mathrm{S}\end{array}$ \\
\hline Trichoderma polysporum & & & & + & + & + & + & + & + & & + & + & & + & + & $\begin{array}{l}\mathrm{KS}, \\
\mathrm{M}, \mathrm{S}\end{array}$ & $\begin{array}{l}\mathrm{KS}, \\
\mathrm{M}, \mathrm{S}\end{array}$ & $\begin{array}{l}\mathrm{C}, \mathrm{KS} \\
\mathrm{M}, \mathrm{S}\end{array}$ \\
\hline Trichoderma viride & & & & & & & & + & + & & & & & & & & $\mathrm{M}$ & $\mathrm{M}$ \\
\hline White non-sporulating colonies & & & & & + & & & + & & & + & & & & & & KS, M & \\
\hline Yeast-like fungi & & & & & & & & & & & + & + & & & & & $\mathrm{KS}$ & $\mathrm{KS}$ \\
\hline \multirow{2}{*}{ Total number of fungal taxa } & 0 & 5 & 5 & 9 & 5 & 7 & 5 & 12 & 5 & 2 & 7 & 6 & 1 & 2 & 2 & \multirow{2}{*}{\multicolumn{2}{|c|}{$\underline{ }$}} & \\
\hline & & 9 & & & 13 & & & 14 & & & 8 & & & 2 & & & & \\
\hline
\end{tabular}

*Abbreviation: C - Chojnik; KS - Kocioł Szrenicki; M - Mumlawski Szczyt; S - Szrenica

Our observations have shown that dead spruce wood, and especially wood in the highest decay classes, was colonized to the greatest degree by Trichoderma spp. Fungi of this genus commonly occur in the natural environment. They are present in soil and are responsible for the decomposition of dead organic tissue [39]. Trichoderma spp. are ubiquitous and colonize dead wood very quickly, although they are unable to colonize living trees. They are frequently isolated from dead spruce wood [39-41]. Interestingly, fungi belonging to this genus (e.g., T. harzianum) may be antagonistic to insects colonizing spruce trees, an example of such an insect being the bark beetle [9]. The insect's defence mechanism against the fungi involves the use of substances produced by the bacterium Micrococcus luteus, which is present in their oral secretions and prevents fungi from growing in the insect-bored corridors [41].
The correlation between wood decay class and composition of wood-decay fungi as well as the frequency of their occurrence was observed in both years of the study. Wood in lower decay classes was colonized by a higher number of fungal taxa compared to wood in decay class 4 or 5. Furthermore, wood in advanced stages of decomposition was mostly colonized by taxa of Trichoderma, particularly in the first year of the study. Our results confirm the observations made by Oszako [42], who isolated more species of fungi from young alder trees (Alnus spp., Betulaceae) than from older specimens, which were mostly infested by Trichoderma spp. Similar results were also obtained by Czekaj and Kowalski [43], as well as Linder [44]. On the other hand, Wrzosek [45] claims that Fusarium spp. is the genus most frequently isolated from dead spruce wood. Fungi belonging to this genus were indeed found during the course of our study. According to the existing 
Table 3. Microscopic fungi isolated from dead spruce wood in 2016: I - spring, II - summer, III - autumn; A (+) indicates the presence of fungi.

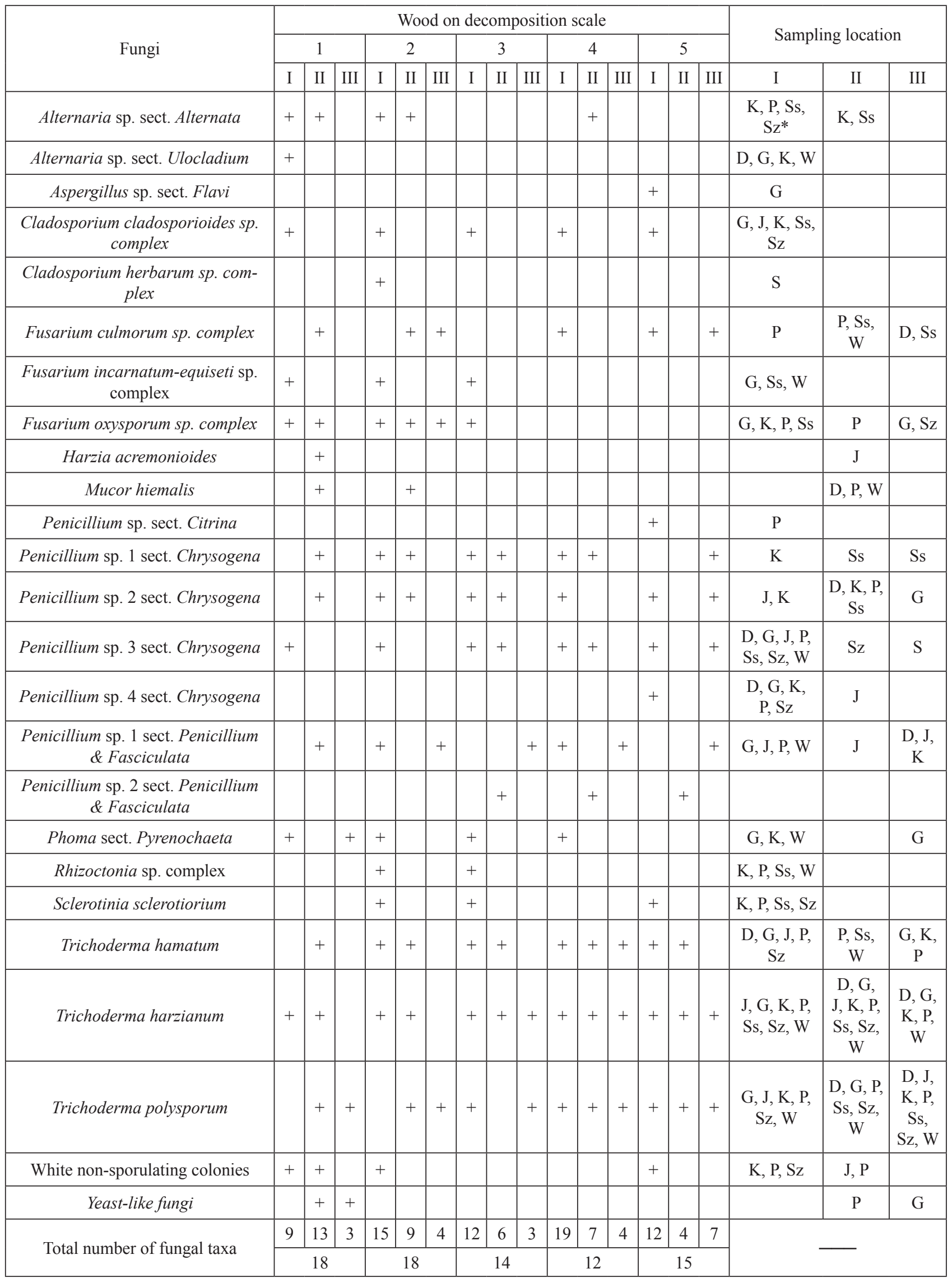

*Abbreviation: D - Dolina Łomniczki; G - Góra Żar; J - Jelenka; K - Kocioł Łomniczki; P - Petrovka; Ss - Skalny Stół; Sz - Szerzawa; W - Wilcza Poręba 
literature, most Fusarium species are plant pathogens, yet their pathogenicity is highly variable even at the intra-species level. As such, in some circumstances saprotrophic forms may develop and use dead organic matter as a substrate [46]. These fungi may also constitute an element of the mycoflora that acts as an inhibitor of natural cycles of renewal, since they pose a threat to seedlings and young trees [9], as well as herbaceous plants [38]. Nevertheless, in environments that experience low human disturbance, Fusarium fungi are a regular component of plant communities and, unlike in agricultural crops or nurseries, their incidence is not of epidemic proportion [47].

The existing scholarly papers [42, 43, 45] seem to conclude that the mycobiota of dead 'post-disturbance' spruce wood found in the Karkonosze Mountains is not significantly different from that of other tree species. Furthermore, they demonstrate a similar positive correlation between the level of Trichoderma spp. colonization and wood decay class. This validates the hypothesis [48] that, despite the ecological disaster that occurred within the area more than 25 years prior to the study, the ecosystem has achieved a state of equilibrium, and the mass occurrence of dead wood together with living organisms capable of decomposing dead organic matter, including fungi, is much the same as in woodland areas experiencing less anthropic disturbance. The conclusion can therefore be drawn that the natural renewal of spruce stands is possible and can be observed in the Karkonosze Mountains. New trees are continually overgrowing the dead stumps as well as the accumulation of spruce trees that died off more than 25 years ago.

\section{Conclusions}

Trichoderma spp. predominated in the mycobiota of dead spruce wood and their proportion increased along with the degree of decomposition. The mycobiota of dead spruce in lower decay classes were characterized by greater biodiversity. The effect of the seasons on the composition of the fungal communities colonizing dead wood was observed, too. The biodiversity of the fungi colonizing dead post-disturbance wood accumulated in the Karkonosze Mountains is not markedly different from that found in other areas or tree species. This lends validity to the claim that the ecosystem of the Karkonosze Mountains is slowly approaching equilibrium after the ecological disaster it suffered 25 years ago.

\section{Acknowledgements}

This study was funded by resources of the forest fund of the "Lasy Państwowe" National Forest Farm, which was transferred to Karkonoski National Park in 2015-2016. Additionally, it was co-financed by the Ministry of Science and Higher Education, and completed thanks to the University of Wrocław's 'Grant to Young Researchers’ (grant No. 0420/2557/18).

\section{Author Contributions}

W.P. designed the experiment, collected all the samples (fieldwork), and performed the analysis. W.P. and R.O. wrote the paper. All the Authors revised the paper and approved the final version.

\section{Conflict of Interest}

The authors declare no conflict of interest.

\section{References}

1. FUDALI E. Ecological assessment of the changes in the moss flora of the glacial cirques in the Polish Karkonosze Mts during XX century. Roczniki Akademii Rolniczej w Poznaniu. Botanika-Steciana, 16, 81, 2012.

2. ŻOLNIERZ L., WOJTUÑ B., MATUŁA J. Vegetation changes in declining spruce forests of the Karkonosze Mountains and the development of plant communities in deforested areas. Opera Corcon. 36, 420, 2000.

3. MANION P.D. Tree disease concepts. Pearson Education, Australia, ISBN 10: 013930701X, 1981.

4. MAZURSKI K.R. The fall of the Sudeten forests. Wszechświat, 115, 4, 2014.

5. ADAMOWICZ K., JASZCZAK R., KUŹMIŃSKI R., GRALA H.S., TURSKI M., ZIENTARSKI J. An attempt at valuation of wood from dead trees in polish forests. Acta Sci. Pol. Silv. Colendar. Rat. Ind. Lignar. 14 (1), 5, 2015.

6. BUJOCZEK L. Decomposition of fallen trees - spruce, beech and fir - in forest ecosystems Sylwan, 156 (3), 208, 2012.

7. SONG Z., KENNEDY P.G., LIEW F.J., SCHILLING J.S. Fungal endophytes as priority colonizers initiating wood decomposition. Funct. Ecol. 31 (2), 407, 2017.

8. GRZYWACZ A. Timber - major ingredient of forest biomass. Studia i Materiały Centrum Edukacji Przyrodniczo-Leśnej, 16.4 (41), 30, 2014.

9. GRZYWACZ A. Biodeversity of fungi occurring in forests Studia i Materiały Centrum Edukacji PrzyrodniczoLeśnej 17.3 (44), 239, 2015.

10. RODRÍGUEZ J., ELISSETCHE J.P., VALENZUELA S. Tree endophytes and wood biodegradation. In A.M. Pirttilä \& A.C. Frank (Eds.), Endophytes of forest trees: Biology and applications. Forestry sciences 80 Berlin, Heidelberg, New York, Springer, 2011, 81, ISBN 978-94-007-1599-8

11. PYLE C., BROWN M.M. A rapid system of decay classification for hardwood logs of the eastern deciduous forest floor. J. Torrey Bot. Soc. 125 (3), 237-245, 1998.

12. OGÓREK R. Mycological air pollutions in Gold Mine (Gertruda's Adit) in Złoty Stok. Proceedings of the $36^{\text {th }}$ Conference of Agricultural Students and Veterinary Medicine with International Participation. Serbia, Nowy Sad, 36, 100, 2012.

13. RIFAI M.A. A revision of the genus Trichoderma. Myc. Papers, 116, 1, 1969. 
14. SCHIPPER M.A.A. A study on variability in Mucor hiemalis and related species. Stud. Mycol., 4, 1, 1973.

15. COLOTELO N. A scanning electron microscope study of developing sclerotia of Sclerotinia sclerotiorum. Can. J. Bot., 52, 1127, 1974.

16. SEIFERT K. Fusarium Interactive Key. Agriculture and Agri food Canada, 1996, 1-65, doi: http://caab.ctu.edu.vn/ gtrinh/fuskey.pdf

17. FRISVAD J.C., SAMSON R.A. Polyphasic taxonomy of Penicillium subgenus Penicillium A guide to identification of food and air-borne terverticillate Penicillia and their mycotoxins. Stud. Mycol., 49, 1, 2004.

18. EKINS M., AITKEN E.A.B., GOULTER K.C. Identification of Sclerotinia species. Australas. Plant Pathol. 34 (4), 549, 2005.

19. CHILVERS M.I., DU TOIT L.J. Detection and identification of Botrytis species associated with neck rot, scape blight, and umbel blight of onion. Online. Plant Health Progress 2006, doi:10.1094/PHP-2006-1127-01DG.

20. GONZÁLEZ GARCÍA V., PORTAL ONCO M.A., RUBIO SUSAN V.. Review. Biology and Systematics of the form genus Rhizoctonia. S.J.A.R. 4 (1), 55, 2006.

21. O'DONNELL K., SUTTON D.A., RINALDI M.G., GUEIDAN C., CROUS O.W., GEISER D.M. Novel multilocus sequence typing scheme reveals high genetic diversity of human pathogenic members of the Fusarium incarnatum- $F$. equiseti and $F$. chlamydosporum species complexes within the United States. J. Clin. Microbiol. 47, 3851, 2009.

22. GRUYTER J., DE WOUDENBERG J.H.C., AVESKAMP M.M., VERKLEY G.J.M., GROENEWALD J.Z., CROUS P.W. Systematic reappraisal of species in Phoma section Paraphoma, Pyrenochaeta and Pleurophoma. Mycologia 102 (5), 1066, 2010.

23. FÁVARO L.CD.L., DE MELO F.L., AGUILAR-VILDOSO C.I., ARAÚJO W.L. Polyphasic Analysis of Intraspecific Diversity in Epicoccum nigrum Warrants Reclassification into Separate Species. PLoS ONE, 6 (8), e14828 2011, doi:10.1371/journal.pone.0014828

24. HOUBRAKEN J., FRISVAD J.C., SAMSON R.A. Taxonomy of Penicillium section Citrina. Stud. Mycol. 70, 53, 2011.

25. KRZYSIAK P., SKÓRKA M., MACURA A.B. Book of human fungal pathogens. MedPharm Polska, Wrocław, Poland, 2011, ISBN 978-83-60466-80-3

26. YAMAZAKI Y., TOJO M., HOSHINO T., KIDA K., SAKAMOTO T., IHARA H., YUMOTO I., TRONSMO A.M., KANDA H. Characterization of Trichoderma polysporum from Spitsbergen, Svalbard archipelago, Norway, with species identity, pathogenicity to moss, and polygalacturonase activity. Fungal Ecol. 4 (1), 15, 2011.

27. BENSCH K., BRAUN U., GROENEWALD J.Z., CROUS P.W. The genus Cladosporium. Stud Mycol, 72, 1, 2012.

28. SHAH S., NASREEN S., SHEIKH P.A. Cultural and morphological characterization of Trichoderma spp. associated with green mold disease of Pleurotus spp. in Kashmir. Res. J. Microbiol. 7, 139, 2012.

29. CROUS P.W., WINGFIELD M.J., GUARRO J., CHEEWANGKOON R., VAN DER BANK M., SWART W.J., STCHIGEL A.M., CANO-LIRA J.F., ROUX J., MADRID H., DAMM U., WOOD A.R., SHUTTLEWORTH L.A., HODGES C.S., MUNSTER M., DE JESÚS YÁÑEZ-MORALES M., ZÚÑIGA-ESTRADA L., CRUYWAGEN E.M., DE HOOG G.S., SILVERA C., NAJAFZADEH J., DAVISON E.M., DAVISON P.J.N.,
BARRETT M.D., BARRETT R.L., MANAMGODA D.S., MINNIS A.M., KLECZEWSKI N.M., FLORY S.L., CASTLEBURY L.A., CLAY K., HYDE K.D., MAÚSSE-SITOE S.N.D., SHUAIFEI C., LECHAT C., HAIRAUD M., LESAGE-MEESSEN L., PAWŁOWSKA J., WILK M., ŚLIWIŃSKA-WYRZYCHOWSKA A., MĘTRAK M., WRZOSEK M., PAVLIC-ZUPANC D., MALEME H.M., SLIPPERS,B., MAC CORMACK W.P., ARCHUBY D.I., GRÜNWALD N.J., TELLERÍA M.T., DUEÑAS M., MARTÍN M.P., MARINCOWITZ S., DE BEER Z.W., PEREZ C.A., GENÉ J., MARIN-FELIX Y., GROENEWALD J.Z. Fungal Planet description sheets: 154-213. Persooni, 31, 188, 2013.

30. CROUS P.W., GROENEWALD J.Z. A phylogenetic reevaluation of Arthrinium. IMA Fungus, 4 (1), 133, 2013.

31. WOUDENBERG J.H.C., GROENEWALD J.Z., BINDER M., CROUS P.W. Alternaria redefined. Stud. Mycol. 75, 171, 2013

32. VISAGIE C.M., HIROOKA Y., TANNEY J.B., WHITFIELD E., MWANGE K., MEIJER M., AMEND A.S., SEIFERT K.A., SAMSON R.A. Aspergillus, Penicillium and Talaromyces isolated from house dust samples collected around the world. Stud. Mycol. 78, 63, 2014.

33. KIM J.Y., KWON H.W., YUN Y.H., KIM S.H. Identification and characterization of Trichoderma species damaging shiitake mushroom bed-logs infested by Camptomyia Pest. J Microbiol Biotechnol 26 (5), 909, 2016.

34. KAMALA TH., INDIRA DEVI S., CHANDRADEV SHARMA K., KENNEDY K. Phylogeny and taxonomical investigation of Trichoderma spp. from Indian region of Indo-Burma biodiversity hot dpot region with special reference to manipur. BioMed Research International 2015, 2015: ID 285261, doi: http://dx.doi.org/10.1155/2015/285261

35. BLACKWELL $M$. The fungi: 1, 2, 3 ... 5.1 million species? AJB 98, 426, 2011.

36. OGÓREK R., DYLĄG M., KOZAK B. Dark stains on rock surfaces in Driny Cave (Little Carpathian Mountains, Slovakia). Extremophiles, 20, 641, 2016.

37. KOKUREWICZ T., OGÓREK R., PUSZ W., MATKOWSKI K. Bats increase the number of cultivable airborne fungi in the "Nietoperek" bat reserve in Western Poland. Microb. Ecol. 72 (1), 36, 2016.

38. PUSZ W. Plants' healthiness assessment as part of the environmental monitoring of protected mountainous area in the example of Karkonosze (Giant) Mountains (SW Poland). Environ. Monit. Assess. 188 (10), 1, 2016.

39. GRONDONA I., HERMOSA R., TEJADA M., GOMIS M.D., MATEOS P.F., BRIDGE P.D., GARCIA-ACHA I. Physiological and biochemical characterization of Trichoderma harzianum, a biological control agent against soilborne fungal plant pathogens. Appl. Environ. Microbiol. 63 (8), 3189, 1997.

40. BŁASZCZYK L., SIWULSKI M., SOBIERALSKI K., LISIECKA J., JĘDRYCZKA M. Trichoderma spp. application and prospects for use in organic farming and industry. JPPR 54 (4), 309, 2014.

41. CARDOZA J., KLEPZIG K., RAFFA K. Bacteria in oral secretions of an endophytic insect inhibit antagonistic fungi. Ecol. Entomol. 31, 636, 2006.

42. OSZAKO T. Fungi identified in dying alder trees. Leśne Prace Badawcze, 2, 96, 2004.

43. CZEKAJ A., KOWALSKI T. Disease symptoms and fungi in dying European ash (Fraxinus excelsior L.). Leśne Prace Badawcze, 71 (4), 357, 2010. 
44. LINDER D., VASAITIS R., KUBARTOVA A., ALLMER J., JOHANNESSON H., BANIK M., STENLID J. Initial fungal colonizer affects mass loss and fungal community development in Picea abies logs 6 yr after iconulation. Fungal Ecol. 4, 449, 2011.

45. WRZOSEK M., SIEROTA Z., SIKORA K., MAŁECKA M., PAWŁOWSKA J. Fungi growing on spruce stumps a year after artificial introduction. Phlebiopsis gigantea. Studia i Materiały CEPL w Rogowie, 41 (4), 202, 2014.

46. WAGAHA J.M., MUTHOMI J.W. Fusarium culmorum: Infection process, mechanisms of mycotoxin production and their role in pathogenesis in wheat. Crop Protection, 26, 877, 2007.
47. PUSZ W., MASCHER F., CZEMBOR E., CZEMBOR J., OGÓREK R. Characterization of the relationships between wheat cultivars, Fusarium Head Blight, and mycoflora grains. Pol. J. Environ. Stud. 25 (3), 1, 2016.

48. JAROCIŃSKA A., ZAGAJEWSKI B., OCHTYRA A., MARCINKOWSKA A., KYCKO A., PABJANEK P. Ecological disaster in the Karkonosze and the Izera Mountains - satellite pictures. Konferencja Naukowa z okazji 55-lecia Karkonoskiego Parku Narodowego „25 lat po klęsce ekologicznej w Karkonoszach i Górach Izerskich - obawy a rzeczywistość” Jelenia Góra, 47, 2014. 
